\title{
Lucius A Nicholls, BA, BL, LSA, MB, B Chir, MD, CMG: father of nutritional science in Sri Lanka
}

I take the opportunity afforded me by the Editor, to write an article for the $C M J$ on a topic of my choice, to sing the praises of an Englishman who served this country for 30 years, retired in 1945, soon to be forgotten. Papers have been published on subjects studied earlier by him without one reference to his work. A PhD thesis that dealt with anthropometry states in the introduction that "Nicholls is said to have published on this topic but his results are not available". I have found 46 of his publications in the library of the Medical Research Institute. There are probably many more.

Lucius A Nicholls was born to Dr and Mrs F L Nicholls on 22 January 1885. He was educated at Downing College, Cambridge, and the London Hospital Medical College, and obtained the BA, BL, MB BChir and MD from Cambridge. He registered as medical practitioner of the UK on 26 April 1906. He worked as Pathologist at Seaman's Hospital, Greenwich in 1907, Surgeon at Victoria Hospital, St. Lucia, British West Indies, between 1908 and 1913, was Captain, East African Medical Services and Officer in Charge, Kadjiada Hospital, British East Africa in 1914/1915. He then took up the post Lecturer in Bacteriology, Ceylon Medical College, and succeeded Dr Aldo Castellani as Director, Bateriology Institute, which he later renamed the Medical Research Institute.

In 1926 he married Eladys Evelyn Johnson (who died in 1946), and had one son and two daughters.

During World War II he was Nutrition Adviser to His Majesty's Service Special Commission on South-East Asia between 1939 and 1945. 1 :nted the then Prime Minister Mr D S Senanayake an $\quad$.. Jefence Commissioner, Mr Oliver E Goonetilleke, and the Assistant CDC., Dr Ivor Jennings (then Vice Chancellor, University of Ceylon), in their efforts to encourage food production and to control food distribution and food prices. He was honoured by the king and made a companion of the Order of St Michael and St George in 1945. On his return to England he was made the Acting Director of the Far East Bureau of the World Health Organisation, from where he retired in 1949.

He spent his retirement in Marlborough, Cork, in the Irish Republic, and Gloucestershire. His last few years were spent in a nursing home in Brighton, Sussex. He died on the 3 September, 1969.

Nicholls was an indefatigable worker and researched in many fields such as bacteriology, parasitology and land snakes, to mention a few. Human and animal nutrition was his main interest, and until the appointment of Dr Ananda Nimalasuriya to the newly formed Department of Nutrition, which he created in 1938, he worked alone.

When he first reported in 1919 his findings on sprue, pellagra and scurvy, the study of vitamins was still in its infancy. "Sprue is caused by an infection by a microorganism, whereas scurvy is more likely to be dependent for its appearance upon a lack of some necessary constituent in the diet. In these respects pellagra falls midway between these diseases. For every suggestion that it is an infectious disease, a contrary opinion exists that its aetiology is explained by the nature of the patient's antecedent diet". He was the first to describe hyperkeratosis, which he found to be common among prisoners in jail and in children in rural schools and orphanages, and coined the term 'phrynoderma'. He wrote, "The disease is due to vitamin A deficiency but other food factors may be at fault". Vitamin A deficiency, he said, was responsible for about $66 \%$ of blindness in the School for the Deaf and Blind, Ratmalana. Nicholls also showed that sore mouth (angular stomatitis and erosion of the tongue) responded to yeast but not to niacin.

Nicholls and Nimalasuriya pointed out that calcium retention by Ceylonese children on a daily intake of about $200 \mathrm{mg}$ was $34 \%$ to $89 \%$, and compared these values with those of European children, whose intake was.about 5 times as high, which ranged from 4 to $36 \%$. The calcium content of bone in Ceylonese compared well with that of Europeans. He postulated that there is a metabolic adaptation to a low calcium intake.

Nicholls was the first (in 1913) to demonstrate the involvement of the liver in malaria. Nicholl's greatest contributions were the numerous and extensive surveys initiated by him in 1933 on anthropometry, food consumption and nutritional status.

Studies on anthropometry showed that the average size is determined more by social status than by race. The height-distance curve for affluent Ceylonese boys was at a higher level than that for British boys, whereas the curves for the less affluent was below the British curve. Affluent Ceylonese girls were also taller than British girls, but they stopped growing earlier, at 16 years, so that adult British females were eventually taller. On the other hand, the weight-distance curves for British children were higher than for Ceylonese. British weight was also dependent on socioeconomic status, and the percentage of low-birth-weight babies was less in the "paying wards" than in the "nonpaying wards" of the De Soysa Maternity Hospital, Colombo.

His studies on food consumption showed that a majority of the population subsisted on a diet of rice, one or two vegetables and coconut. From 16 to 18 ounces (454 to $511 \mathrm{~g}$ ) per head, of rice and rice flour were eaten. About $28 \mathrm{~g}$ of pulses such as green gram or lentil were included in the meal every other day. Only a few could afford milk. Consumption of meat, eggs, butter and ghee was negligible, breadfruit and jak were eaten in season, and the commonest fruit taken was the banana. The average dietary energy consumption of the poorer classes was about $1900 \mathrm{kcal}$, and among these, the blemishes of malnutrition were seen extensively. 
Such reports resulted in the Secretary of State for the Colonies asking all colonial governments to submit reports on the status of nutrition in their territories. Their reports were studied by the Colonial Office Committee under the Chairmanship of Rt Hon Earl de la Waar, which considered that, "we have no doubt that improved nutrition will bring greater benefit to the Colonial Empire. In saying this we do not have primarily in mind the eradication of deficiency disease, though this, in itself, is an important enough field of work. More important than the effect of malnutrition in directly producing disease is its effect in producing illhealth and lowered resistance to other diseases, a high infant and maternal mortality and a general lack of wellbeing".

Nicholls' work also resulted in various committees being appointed to inquire into diets of prisoners in jail and patients in hospitals, and the availability of milk in the country. As a result, the diets in these institutions were greatly improved, public lectures given, the local press co-opted and a great awareness of nutritional problems created. The colonial government took note of the poor state of nutrition of the vernacular school children, and in 1937, voted one million Rupees for the provision of a midday meal of rice and curry. The Department of Agriculture became active in increasing locally grown foods and in improving animal husbandry. The consumption of locally grown under-milled, parboiled rice was encouraged by the newly set up Marketing Department.

A committee headed by Dr S T Gunasekera recommended the setting up a Nutrition Department at the Bacteriology Institute, and an intensification of nutrition education of health workers. "It is desirable to take sound measures for teaching of tropical dietetics to all medical officers, some of whom will hand over their knowledge to schoolmasters and others". Nicholls initiated a course of lectures on nutrition to all medical students during their fourth year and nutrition formed part of the course of study of nurses and public health inspectors.

Nicholls wrote two books, "Eat and be Healthy" and "Tropical Nutrition and Dietetics" which went into 4 editions and became a standard text for students of nutrition world-wide.

The Gunasekera Committee also recommended that "the simpler principles of tropical hygiene and dietetics be a compulsory subject in all schools and in the examinations". Nutrition and dietetics have still to become a compulsory subject at school examinations. Primers are only now being prepared.

With the advent of World War II it became necessary to initiate a food rationing scheme. A ration of rice was issued weekly at a subsidised rate that ensured that a minimum quantity was made available to everyone. Rice was supplemented with wheat and other grains such as bajra, and rice consumption fell to about $200 \mathrm{~g}$ per day. The Food Commissioner's Department, set up in 1942, was given the task of distributing a weekly rice ration of $21 / 2 \mathrm{lb}$ for everyone at subsidised rates, through co-operative stores. The rice ration was continued even after the war was over, and ensured a minimum energy supply to the poor. It is considered the best nutrition intervention that Sri Lanka has seen.

I had the privilege of being taught both bacteriology and nutrition by him. I remember him with respect, and affection.

T W Wikramanayake, Professor Emeritus, University of Peradeniya. 